Zusammenfassung. 1979 berichtete Angelchick über eine Silikon-Antirefluxprothese. In tierexperimentellen und klinischen Untersuchungen an Patienten mit Refluxkrankheit konnte gezeigt werden, da 1 1. die klinischen Resultate der Antirefluxprothese mit denen nach Nissen-Fundoplicatio vergleichbar sind, 2. die Silikonprothese im Vergleich zur Fundoplicatio einfacher anzulegen, die Operation kürzer und risikoärmer ist, 3. ob postoperative Komplikationen nach Silikonprothesen seltener sind als nach Fundoplicatio ( $20 \%$ ), muß zur Zeit noch offen bleiben.

Schlïsselwörter: Gastro-oesophagealer Reflux - Silikon-Antirefluxprothese.

\title{
242. Das Ulcus pepticum jejuni (Upj) nach Magenresektion
}

\author{
M. M. Linder, Ch. Petermann, H. Gai, R. Reffert und R. Rethel ${ }^{1}$ \\ Chirurgische Klinik (Prof. Dr. M. Trede) und ${ }^{1}$ I. Medizinische Klinik (Prof. Dr. D. Heene), \\ Klinikum Mannheim der Universität Heidelberg, Theodor-Kutzer-Ufer, D-6800 Mannheim
}

\section{Anastomotic Ulceration Following Gastric Resection for Peptid Ulcer}

\begin{abstract}
Summary. From 1972 to 1981 (10 years) 106 patients with anastomotic ulceration following gastric resection were treated in the Klinikum Mannheim: 51 operatively (lethality: $7.8 \%$ ) and 55 conservatively (lethality: $2 \%$ ). Of the 81 surviving patients $60(74 \%)$ could be examined in 1982 . Frequency of satisfactory Visick grades I - III was higher in the operative group ( $59 \%$ ) compared with $45 \%$ in the conservative group. Cumulative recurrency was lower in the operative group with $31 \%$ as opposed to $48 \%$. Even though the operative cases presented with more serious disease, surgical therapy ( $72 \%$ resection, $65 \%$ additional vagotomy, $8 \%$ vagotomy alone) obtained more favourable results.
\end{abstract}

Key words: Peptic ulcer - Gastric resection - Anastomotic ulceration - Operative and conservative treatment.

Zusammenfassung. Von 1972 bis 1981 wurden 106 Patienten mit Ulcus pepticum jejuni im Klinikum Mannheim behandelt: 51 operativ (Letalität 7,8\%) und 55 konservativ (Letalität: $2 \%$ ). $60(74 \%$ ) der 81 Überlebenden konnten durchschnittlich 5 Jahre später 1982 nachuntersucht werden. Die Frequenz der befriedigenden VisickNoten I- IIIs war mit $59 \%$ in der operativen Gruppe höher als in der konservativen (45\%). Die kumulative Rezidivrate war in der operativen Gruppe niedriger mit $31 \%$ gegenüber $48 \%$. Obwohl die operativen Patienten die schwereren Fälle darstellten, erzielte die Chirurgie ( $72 \%$ Nachresektion, zusätzlich Vagotomie $65 \%$, Vagotomie allein : $8 \%$ ) bessere Ergebnisse.

Schlïsselwörter: Ulcus pepticum jejuni - Magenresektion - Operative und konservative Therapie.

\section{Langzeitergebnisse nach elektiv und notfallmäßig durchgefïhrter selektiv proximaler Vagotomie}

\author{
D. H. Wittmann, H. Kirschner und S. Luetkens \\ I. Chirurgische Abteilung (Chefarzt: Prof. Dr. H. Kirschner) des Allgemeinen Krankenhauses Altona, \\ Paul-Ehrlich-Straße 1, D-2000 Hamburg 50
}

\section{Long-Term Results After Elective and Emergency Selective Proximal Vagotomy}

Summary. From 1970 to 1979,310 patients ( $79 \%$ male, $14 \%$ foreigners) with duodenal ulcer ( $71 \%$, gastric ulcer $(18 \%$, and combined ulcers $(5.4 \%)$ were operated on by 27 surgeons (277 elective and 33 emergency operations). Until 1976 a pyloroplasty was combined with selective proximal vagotomy (Holle). The operative mortality was $0.3 \%(0 \%$ after elective and $1 \%$ after emergency operations); the total mortality was $2.2 \% .(2$ after 277 elective and 5 after 33 emergency operations). Intraoperative complications were seen in $2.9 \%$ ( 5 splenic and 3 esophageal lesions) and postoperative complications in $13 \%$ (pulmonary infections in 19 cases). Follow-up was possible up to 10 years in $91 \%$ of the cases. Mild dumping symptoms were seen in $12.2 \%$ and mild diarrhea in $1.3 \%$. Recurrent ulcerations were observed at endoscopy in 22 patients $(8.1 \%)$. The 72 patients having primary gastric ulcerations experienced 5 recurrences $(6.1 \%)$, all located in the stomach.

Key words: Selective proximal vagotomy - Duodenal ulcer - Gastric ulcer - Long-term results. 